\title{
The Impact of Media on Mobility: The Case of Ethiopian Migrants in the West
}

\author{
Samuel Mochona Gabore \\ https://orcid.org/0000-0003-1064-8540 \\ Huazhong University of Science and Technology, School of Journalism and Communication, China
}

\begin{abstract}
As a recent phenomenon, increasing number of Ethiopians are leaving their country and trying to reach the West. The pull and push factors range from expecting better opportunities in the destination to fleeing political persecution. Combining survey data from Ethiopian Diaspora with information from international and national migration organizations, this study explores which media play key roles in migration of people. Over the period of 15 years, from 2000 to 2014, a steadily increasing number of Ethiopians have been migrated to countries such as United States, Canada, Germany, Israel, Norway and Sweden. These countries are either broadcasting traditional media to Ethiopia or having strong Ethiopian social media networks. In making migration decisions, consumption of Western media and prior existence of networks play crucial roles. There has been constant or increasing number of migration to the countries which transmit media, radio and television, particularly in Ethiopian languages and where there are large numbers of Ethiopian Diasporas. In addition, social media is playing important roles in facilitating migration by creating and maintaining networks (connectivity) and providing information. Matchmaking sites are also contributing significantly by creating connectivity that eventually leads to marriage migration.
\end{abstract}

DOI: $10.7176 / \mathrm{NMMC} / 77-02$

\section{Introduction}

Mobility is the temporary or permanent change of residential or geographic location of individuals or groups of people within a city or across continents for various reasons ranging from better employment possibilities to fleeing persecution (Hagen-Zanker, 2008; Gregory et al., 2009). To make migration decisions, potential migrants seek information from different sources. Media such as television and social media as well as connectivity with Diaspora networks provide information on opportunities at destination, costs and processes of migration, and assistant to migrants.

Migration theories explain that media play important roles in mobility. Extant literature shows that people migrate even when economic benefits cease to exist due to the existence of networks (Liebig 2003, Massey et al. 1993, Hagen-Zanker, 2008). According to Mai (2004), the relation between media consumption and mobility can be explained in terms of a magnetic attraction of countries that receive Western television programmes and send migrants to countries that send television programmes and receive migrants in return. New technologies and social media made migration easier by increasing the number of friends and relations abroad who can be found and might be willing to provide assistance (Komito, 2011).

Despite theoretical explications of the relationships between media and mobility, empirical research on impact of media on migration has been extremely limited. In this regard, this studyr examines the role of the media, both traditional and social media, on facilitating connectivity and mobility of Ethiopians to the Western countries. Western media consumption in Ethiopia, roles being played by social media and matchmaking sites, existence of the Ethiopian Diasporas in the destination, and migrations of Ethiopians from 2000 to 2014 to the West were studied to determine the impact of the media on connectivity and mobility. West in this study is taken very broadly and it includes United States, Canada, Europe, Australia and Israel.

\section{Literature Review}

\subsection{Why Do People Migrate?}

Migration theories, (Massey et al., 1993), explain that people move from one location to another for economic, cultural, Social, political, environmental or other reasons. Neoclassical theory migration assumes that people migrate primarily for economic benefits in the push-pull framework (Massey et al., 1993; Liebig, 2003; Bodvarsson and Van den Berg, 2013). For the human capital theory of migration that enriches the neoclassical framework by incorporating the socio-demographic characteristics of the individual migrant, a rational individual migrates with the goal of maximizing his or her benefits and gains (Bodvarsson and Van den Berg, 2013; Kurekova, 2011). The new economics of migration theory argues that migrations decisions, influenced by conditions in the home country, are made by families or households but not by isolated individual actors (Massey et al., 1993, Liebig, 2003). Migration, according to the world system theory, is determined by structural change in world markets and it is a function of globalization (Hagen-Zanker, 2008; Kurekova, 2011). Similarly, dual labor market theory links migration to structural changes in the market but explaining its 
dynamics with the demand side rather than supply (Massey et al., 1993; Hagen-Zanker, 2008; Kurekova, 2011). The network theory of migration that explains why migration continues even when economic benefits cease to exist focuses on what perpetuates migration in time and space looks at the existence of a Diaspora or networks (Liebig, 2003; Massey et al., 1993; Hagen-Zanker, 2008). As explained in migration systems theory, migration a response to "prior existence of links between sending and receiving states," (Kurekova, 2011). On the other hand, cumulative causation conception argues that migration is a self-perpetuating and self-sustaining phenomenon and identifies factors such as networks, culture of migration, perverse distribution of human capital and the stigmatization of jobs generally performed by migrants (Massey et al., 1993; Kurekova, 2011). The theory of transnational migration conceptualizes the existence of transnational social spaces with multiple forms of migrant embedding who stay connected and actively participate in both home and host country political, economic, social and cultural environments (Kurekova, 2011). Institutional theory conceptualizes the role played by private institutions and voluntary organizations in terms of filling the demand gap created by a large number of people seeking entry into rich countries and the limited number of immigrant visas granted resulting in formation of dedicated institutions promoting international movement for profit and a black market in migration (Massey et al., 1993).

\subsection{Media, Connectivity and Mobility}

Among the theories of migration, the network theory of migration, migration systems theory, and the theory of transnational migration show that media and connectivity plays important roles in mobility. These theories argue that migration continues even when economic benefits cease to exist due to the existence of networks (Liebig 2003, Massey et al., 1993, Hagen-Zanker, 2008). And it is also explained that migration is a response to prior existing connectivity between the origin and destination of the migration and those who stay connected and actively participate in both home and host country political, economic, social and cultural environments through media and other networks are likely to migrate (Kurekova, 2011). In addition, networks perpetuate migration (Massey et al., 1993) and in the existence of networks, migration continues even when wage differentials cease to exist or where there are no supportive recruitment policies. The existence of networks is likely to influence the decisions of migrants when they choose their destinations. The existence of networks is likely to influence the decisions of migrants when they choose their destinations ((Hagen-Zanker, 2008). Individuals often go to where they already have contacts (Komito, 2011).

Providing information on possible destination regions is a crucial role played by networks for individual decisions to be made by migrants. By providing information on the migration process, facilitating the access to the job market and helping integration upon arrival, networks are crucial in perpetuating migrations. Networks, therefore, are a source of information, but they also directly reduce migration costs and influence employment outcomes at destination (Farre and Fasani, 2011).

In relation with media consumption and mobility, Mai (2004) says the relation between media consumption and mobility can be explained in terms of a magnetic attraction of countries that receive Western television programmes and send migrants to countries that send television programmes and receive migrants in return. Migrants are encouraged by hopes of success, pushed by necessity and by the imaginary world provided by television and other media.

New technologies and social media made migration easier by increasing the number of friends and relations abroad who can be found and might be willing to provide assistance. New technologies have also facilitated the emergence of transnational identities, that is, individuals who view themselves as members of a national or ethnic group despite the fact that they do not live in the geographical areas associated with those nations or ethnicities. Social media enhance migrants' capacities to maintain family and kinship contacts across long distances, to create extensive personal networks and their social media practices enable a shared experience with friends and relations living outside of their home country (Komito, 2011).

Dekker and Engbersen (2012) identified four key functions of social media, which transform migrant networks and facilitate migration:

(1) Strengthening strong ties with family and friends;

(2) Creating ties to individuals that can assist in the process of migration (and integration);

(3) Creating a network of latent ties; and

(4) Creating a rich source of insider knowledge on migration.

Combined, these functions can serve to reduce the costs of migration through both reducing the emotional cost of separation and through allowing access to both information and contacts that can assist the migrant in having a smooth relocation.

Another media type, which can be considered as social media are matchmaking sites that serve as a tools for marriage migration. Presently, millions of individuals are engaged in online dating. Millions of messages are exchanged and thousands of connections are made through matchmaking sites resulting in increased mobility and migration as people travel long distances for romantic attachments (Tamerler, 2014). Children and 
grandchildren of earlier migrants have continued to marry partners from their ancestral countries of origin. To maintain national identification and an orientation towards the homeland, these people see migrant spouses as importing traditional values (Charsley et al., 2016). There are thousands of matchmaking sites that facilitate relationship formation between Ethiopian men and women in Western countries and homeland. As a result, thousands of single men and women leave their country by marrying or to marry a person of Ethiopian origin in the West.

Based on the theoretical discussion the following research questions were formulated and the present study attempts to answer.

RQ1. What does Western media consumption in Ethiopia look like?

RQ2. What are the roles played by the media?

RQ3. What are the major migration trends?

\section{Method}

Survey data was collected in December 2016 from 250 Ethiopian migrants, 50 individuals, in each of the United States, Canada, Europe, Australia and Israel to study migrations of Ethiopians from 2000 to 2014 to the West. Secondary data was also collected from Migration Policy Institute report 2014 and Global Migrant Origin Database 2016

\section{Result}

\subsection{Western Media Consumption in Ethiopia}

There is high Western media consumption in Ethiopia including media transmitted by Ethiopian Diaspora community. Most of these media are tailor-made in Ethiopian languages for Ethiopians. Throughout their programmes, the media portray a tantalizing image of western life which seduces people to make migration decision. These media broadcast in Ethiopian languages either by Ethiopian Diasporas or the governments of the Western countries. Survey data, $86 \%$ of the participants reported that Western media consumption indirectly motivated them to make migration decisions.

Table 1: Western Media Consumed in Ethiopia

\begin{tabular}{|c|c|c|c|c|}
\hline Media Name & $\begin{array}{l}\text { Type of } \\
\text { Media }\end{array}$ & $\begin{array}{ll}\text { Origin } & \text { of } \\
\text { Transmission }\end{array}$ & Ownership & $\begin{array}{l}\text { Consumption of media before } \\
\text { migration decision }(\%)\end{array}$ \\
\hline VOA Amharic & Radio & United States & $\begin{array}{l}\text { U.S. } \\
\text { government }\end{array}$ & $235(94)$ \\
\hline DW Amharic & Radio & Germany & $\begin{array}{l}\text { German } \\
\text { government }\end{array}$ & $242(97)$ \\
\hline EBS & Television & United States & $\begin{array}{l}\text { Ethiopian } \\
\text { Diaspora }\end{array}$ & $\begin{array}{l}0 \text { (media was established after the } \\
\text { informant was migrated) }\end{array}$ \\
\hline E-Sat & Television & United States & $\begin{array}{l}\text { Ethiopian } \\
\text { Diaspora }\end{array}$ & $\begin{array}{l}0 \text { (media was established after the } \\
\text { informant was migrated) }\end{array}$ \\
\hline $\begin{array}{l}\text { E-Sat } \\
\text { Amsterdam }\end{array}$ & Television & Netherlands & $\begin{array}{l}\text { Ethiopian } \\
\text { Diaspora }\end{array}$ & $\begin{array}{l}0 \text { (media was established after the } \\
\text { informant was migrated) }\end{array}$ \\
\hline $\mathrm{OMN}$ & Television & United States & $\begin{array}{l}\text { Ethiopian } \\
\text { Diaspora }\end{array}$ & $\begin{array}{l}0 \text { (media was established after the } \\
\text { informant was migrated) }\end{array}$ \\
\hline $\begin{array}{l}\text { Meret } \quad \text { Ethio } \\
\text { Israel }\end{array}$ & Television & Israel & $\begin{array}{l}\text { Ethiopian } \\
\text { Diaspora }\end{array}$ & $\begin{array}{l}0 \text { (media was established after the } \\
\text { informant was migrated) }\end{array}$ \\
\hline ETN & Television & UK & $\begin{array}{l}\text { Ethiopian } \\
\text { Diaspora }\end{array}$ & $\begin{array}{l}0 \text { (media was established after the } \\
\text { informant was migrated) }\end{array}$ \\
\hline
\end{tabular}

\subsection{Roles Played by the Media}

Survey data show that migration decisions were strongly influenced by traditional media description of Western countries and connections created by the new media. For $89 \%$ of the migrants social media have strengthened ties with family and friends in the West. All of the migrants reported that social media have created ties to individuals who can assist in the process of migration and integration. In addition $92 \%$ responded that the media has served as a rich source of insider knowledge on migration. Many of those who take the risks of migration are single young men and women who, after securing green card or similar legal documents, facilitate the mobility of another group for marriage migration through Ethiopian matchmaking sites.

\subsection{Mobility Trends among Ethiopian Migrants}

Migration has been a recent phenomenon for Ethiopians. During the 1960s and early 1970s, most Ethiopians in the United States and Europe were students or diplomats and other members of the political and educated elite 
and thus predominantly temporary migrants. Between 1942 and 1970, the number of Ethiopian students in European and North American countries rose from 200 to 5,000. The majority of these professional or educational migrants usually returned to Ethiopia upon completion of their studies or missions. This changed with the fall of Emperor Haile Selassie and the seizure of power by the Communist government, the Derg, in 1974. Especially during the years of the Red Terror (1977 to 1982), former supporters of the Emperor as well as members of the moderate leftist opposition fled the country and usually received unlimited residence permits in Western countries as they were officially recognised as political refugees.

In recent years, following the 2005 election crisis, the repressive political climate has prompted many supporters of opposition movements to leave the country again. Most Ethiopians fled to Sudan and Middle Eastern countries. Today, the largest Ethiopian community outside of the Horn of Africa exists in the United States, with an estimated total of from 250,000 to 500,000 individuals. Approximately 60 percent of the Ethiopian immigrants are those who arrived in the United States after 2000 (Migration Policy Institute 2014). In Europe, the largest Ethiopian Diasporas are to be found in Sweden, Germany, the United Kingdom and the Netherlands .

Table 2: Number of foreign-born Ethiopians in some Western countries

\begin{tabular}{|l|l|}
\hline Country & Number \\
\hline U.S. & 73,066 \\
\hline Sweden & 11,281 \\
\hline Germany & 9,542 \\
\hline Canada & 14,486 \\
\hline United Kingdom & 8,122 \\
\hline Israel & 58,900 \\
\hline Netherlands & 7,592 \\
\hline Norway & 3,575 \\
\hline
\end{tabular}

Source: Global Migrant Origin Database

In addition to the migrants, there are also second generation Ethiopians who were born in the Western countries. These are also part of the Ethiopian networks that facilitate mobility of Ethiopians. Table 2 shows the number of foreign-born Ethiopians in Western countries who potentially create fertile ground for the migration networks and marriage migration.

Increasing number of Ethiopians particularly more rural people are leaving their country and trying to reach Europe, Israel, Saudi Arabia, or South Africa even in an undocumented manner following risky routes and using smugglers (IRIN 2011). A study by the Danish Refugee Council (DRC) and Regional Mixed Migration Secretariat (RMMS) reveal that Ethiopians, the world's largest group of irregular migrants face kidnap, torture, sexual violence, abduction and extortion (DRC and RMMS 2012). Thousands of young Ethiopians, who are aware of the risks irregular Ethiopian migrants face, are still leaving the country by taking 'illegal' routes (Hussein 2015). Among the perilous journey migrants are those who expect to reach South Africa and then to the West taking the route via Kenya, Uganda, Tanzania and Zimbabwe through the highest possible risks ranging from torture to death (Maru 2015). The United States is the most common destination for the emigrants (Migration Policy Institute 2014).

According to (DRC and RMMS 2012), the pushing force behind the majority of Ethiopian migrants is the lack of economic opportunities in the country. On the other hand, Hussein (2015) argues, “... the vast majority of Ethiopian migrants are political refugees fleeing persecution." The migration decision is made as a result of socio-economic factors such as networks and availability of opportunities. Kanko et al. (2013) conclude that the major cause of irregular migration is availability of better opportunities in more developed countries.

As the data in Table 3 indicate there has been steadily increasing number of migration to United States, Canada, European countries, Israel and Australia.

Table 3: Number of Ethiopians migrated to Western Countries

\begin{tabular}{|c|c|c|c|c|c|c|c|c|c|c|c|c|c|c|c|}
\hline \multirow[b]{2}{*}{ Destination } & \multicolumn{15}{|c|}{ Year } \\
\hline & 2000 & 2001 & 2002 & 2003 & 2004 & 2005 & 2006 & 2007 & 2008 & 2009 & 2010 & 2011 & 2012 & 2013 & 2014 \\
\hline U.S. & 4053 & 5092 & 7565 & 6635 & 8286 & 10573 & 16157 & 12786 & 12917 & 15462 & 14266 & 13793 & 14544 & 13097 & 12300 \\
\hline Sweden & 191 & 192 & 170 & 201 & 245 & 252 & 454 & 491 & 518 & 795 & 958 & 654 & 662 & 597 & 774 \\
\hline Germany & 863 & 822 & 1019 & 981 & 887 & 589 & 582 & 618 & 719 & 789 & 931 & 1051 & 1124 & 1337 & 1752 \\
\hline Canada & 1039 & 1009 & 802 & 1399 & 1535 & 1506 & 1801 & 1512 & 1613 & 1289 & 1865 & 2163 & 1864 & 1606 & 1340 \\
\hline Australia & 386 & 384 & 391 & 618 & 698 & 615 & 477 & 520 & 476 & 751 & 825 & 731 & 801 & 437 & 679 \\
\hline Israel & 2203 & 3272 & 2656 & 3029 & 3693 & 3571 & 3595 & 3589 & 1582 & 239 & 1655 & 2666 & 2432 & 1355 & 211 \\
\hline Netherlands & 171 & 205 & 212 & 231 & 229 & 235 & 250 & 280 & 266 & 274 & 281 & 237 & 248 & 244 & 230 \\
\hline Norway & 306 & 419 & 337 & 272 & 245 & 372 & 271 & 420 & 425 & 631 & 479 & 508 & 540 & 582 & 544 \\
\hline
\end{tabular}

Data extracted from OECD.Stat, International Migration Database, December, 2016

In these Western countries, there are a number of Ethiopian networks to which new migrants form 
connectivity to get information on opportunities and processes of migration. There are online social media pages where such information is shared in addition to individual connectivity on telephone, email and different messenger applications.

\section{Discussion and Conclusions}

Classical migration theories assume that people migrate primarily for economic benefits or migration is determined by structural change in world markets and it is a function of globalization. On the other hand, the network theory of migration that argues why migration continues even when economic benefits cease to exist explains that migration in time and space is the outcome of the existence of networks or connectivity. Similarly, migration systems theory, clarifies that migration is a response to prior existence of links between sending and receiving countries.

The relation between Western media consumption and migration to the West is highly correlated that countries that receive Western media programmes are most likely to send migrants to countries that send television programmes and receive migrants in return. Similarly, social media enhance migration by creating a rich source of insider knowledge on migration and creating ties to individuals that can assist in the process of migration. Matchmaking sites are also serving as a tool for marriage migration.

As a recent phenomenon, an increasing number of Ethiopians are migrating to the Western countries. Over the period of 15 years, from 2000 to 2014, a steadily increasing number of Ethiopians have been migrated to countries such as United States, Canada, Germany, Israel, Norway and Sweden. These countries are either broadcasting traditional media to Ethiopia or having strong Ethiopian social media networks. The mobility of Ethiopians to the West is highly correlated with Western media consumption and connectivity to the Ethiopian Diaspora in the countries. The impact of media on connectivity and mobility is very high.

\section{References}

Bodvarsson, O.B. and Van den Berg, H. (2013). The Economics of Immigration: Theory and Policy. New York: Springer Science \& Business Media

Dekker, Rianne and Engbersen, Godfried (2012). How social media transform migrant networks and facilitate migration. International Migration Insitute

DRC and RMMS (2012). Desperate choices: conditions, risks and protection failures affecting Ethiopian migrants in Yemen. http://regionalmms.org/fileadmin/content/rmms_publications/Desperate_Choices.pdf

Farre, L. and Fasani, (F. 2011). Media Exposure and Internal Migration: Evidence from Indonesia. Discussion Paper No. 6012. Forschungsinstitut zur Zukunft der Arbeit (Institute for the Study of Labor)

Gregory, D. et al. (2009). The dictionary of Human Geography, 5th edition. Blackwell Publishers Ltd

Hagen-Zanker, J. (2008). Why do people migrate? A review of the theoretical literature. Maastricht University

Hussein, H. (2015). If Ethiopia is so vibrant, why are young people leaving? http://america.aljazeera.com/opinions/2015/4/if-ethiopia-is-so-vibrant-why-are-young-people-leaving.html

IRIN (2011). Ethiopia: Cautionary migration tales are no deterrent, http://www.irinnews.org/report/94279/ethiopia-cautionary-migration-tales-are-no-deterrent

Kanko et al. (2013). IRREGULAR MIGRATION: Causes and Consequences of Young Adult Migration from Southern Ethiopia to South Africa: Paper Presented at the XXVII IUSSP International Population Conference from 26-31 August, 2013 Busan, South Korea

Charsley, K., Bolognani, M., Spencer, S., Ersanilli, E., Jayaweera, H. (2016) Marriage Migration and Integration Report, Bristol, UK: University of Bristol

Komito, Lee (2011). Social Media and Migration: virtual community 2.0. Journal of the American Society for Information Science and Technology 2011, v. 62 (6), pp. 1075-1086. 2011.

Kurekova, Lucia (2011). Theories of migration: Conceptual review and empirical testing in the context of the EU East-West flows. Central European University

Liebig, Thomas (2003). Migration Theory from A Supply- Side Perspective. Switzerland: University of St. Gallen

Mai, Nick (2004). 'Looking for a More Modern Life...': the Role of Italian Television in the Albanian Migration to Italy. Westminster Papers in Communication and Culture (University of Westminster, London), Vol. 1(1): 3-22. ISSN 1744-6708

Maru, $\quad$ M. $\quad$ T. (2015). Migration governance in $\quad$ Ethiopia. http://www.thereporterethiopia.com/index.php/opinion/commentary/item/3481-migration-governance-inethiopia

Massey, et al. (1993). Theories of International Migration: A Review and Appraisal, Population and Development Review, Vol. 19, No. 3 (Sep., 1993), pp. 431-466, Population Council

McGregor, Elaine and Siegel, Melissa (2013). Social Media and Migration Research. Maastricht Economic and social Research institute on Innovation and Technology (UNU - MERIT), Maastricht, The Netherlands 
Migration Policy Institute (2014). The Ethiopian Diaspora in the United States. RAD Diaspora Profile

Min-Harris, Charlotte (2010). Youth Migration and Poverty in Sub -Saharan Africa: Empowering the Rural Youth. http://www.du.edu/korbel/hrhw/researchdigest/africa/YouthMigration.pdf.

Organisation for Economic Cooperation and Development (2016). OECD.Stat https://stats.oecd.org/Index.aspx?DataSetCode=MIG

Tamerler, Kevin (2014). How Far Will We Go for (Online) Love? A Study of the Geographical Effects of Online Dating. Hofstra University

Warnecke, Andrea (ed.) (2010). A Comparative Assessment of Somali and Ethiopian Communities in Europe. Bonn International Centre for Conversion 